\title{
The Current Situation and Optimization of College Counselors' Continuing Education
}

\author{
Xianghua Ren \\ Youth League Committee \\ Shandong Technology and Business University \\ Yantai, China
}

\begin{abstract}
The status of counselors in colleges and universities in China is relatively low, and the continuing education of counselors has not been paid much attention. Therefore, the current situation of counselors' continuing education is not optimistic. In view of the problems existing in the current situation of counselors' continuing education, it is of great significance to find out the optimized path of continuing education for counselors. Counselors are an important group of college teachers and they shoulder the responsibility of students' ideological and political education and the maintenance of campus harmony and stability. The training level of counselors' continuing education not only relates to the career development of counselors, but also to the future of students and colleges. Various kinds of relevant policies, regulations and implementing rules are promulgated successively, which make clear and specific stipulation to the continuing education work of college counselors, and ensure the institutionalization, standardization and normalization of the continuing education.
\end{abstract}

Keywords-counselors; continuing education; current situation; optimized path

\section{INTRODUCTION}

\section{A. Weak Awareness of Continuing Education for Counselors}

The continuing education of counselors is an important means to improve the professional literacy of counselors and to strengthen the professional identity of counselors. Both schools and counselors should pay close attention to the continuing education of counselors. However, it seems that nowadays no matter whether it is the college or the counselors themselves, the awareness of counselors' continuing education is relatively weak. They cannot really understand the importance of continuing education, and do not pay enough attention to and attach importance to the work of counselors' continuing education. This is mainly reflected in three aspects: First, schools do not pay enough attention to the counselor's work, and the support to the counselor's continuing education is insufficient. Second, counselors themselves did not strive for continuing education rights and career planning awareness. Compared with other teaching teachers who participated in the work in the same period, counselors have more tired work, the lower status, the worse treatment and the unclear development prospects, therefore, many counselors do not form professional identity for their work, nor do they have the so-called career development consciousness. Individual counselors will even consider work as a springboard, and take continuing education and training as shortcuts to job-hopping, so the importance and significance of continuing education and training are not fully understood. Third, the school's role in the guidance of counselors is vague, resulting in the counselors' continuing education and training lack of focus. In most colleges and universities, counselors not only act as the role of ideological and political teachers, but also serve as the role of student life teachers, and some even think of counselors as "nannies" of college students.

\section{B. Backwardness of the Continuing Education System for Counselors}

Most colleges and universities in our country lack a complete continuing education and training system for counselors, and their training methods and contents are relatively backward. First of all, the system of continuing education of counselors is not perfect, which makes the continuing education and training of counselors have no basis. Although the State has promulgated a number of documents to emphasize and deploy the work of college counselors' continuing education and training at the macro level, there are no detailed provisions on how to carry out the training of counselors' continuing education and what principles and standards should be followed in each university, which lead to continuing education and training of counselors mostly "in the text level, lack of practical operability or strict implementation"[1], so these documents have no practical binding effect on the continuing education of counselors. Second, the counselor's continuing education training model is unitary. Most colleges and universities in the continuing education and training of counselors are basically simply relying on the university, mainly by the relevant departments of the school to arrange the expert lectures and short-term training. These trainings are narrow in audience, training mode is extremely simple and arbitrary, closed and backward, time and place are relatively limited, and they are mere formality and have not formed a socially oriented and international-oriented open situation that cannot meet the new needs of undergraduates and the new requirements of the reform and development of higher education. Finally, the education system developed by 
counselors has not been established. Continuing education for counselors requires a professional foundation to be more effective. However, at present, there are almost no specialties in training counselors in our country, and most colleges and universities do not have a formal education system for counselors at all. As a result, the work of college counselors cannot rely on the professional knowledge, so that the counselors lose the means of research, "Counselors continuing education is like water without a source and a tree without roots."[2]

\section{Worring Quality of Contiuing Education for Counselors}

The low quality of counselors' continuing education is the most serious problem facing college counselors' continuing education and it is the direct consequence of many problems in the current situation of continuing education as well. First of all, there is no formal training and no corresponding evaluation criteria for the counselors' continuing education, and there is no restriction mechanism to the trainees. This leads to the situation that the counselor's continuing education and training line has no basis, no evidence and no learning, causing the confusion in the current situation of continuing education and training for counselors. Second, the instructor's continuing education and training courses lack of pertinence. Most of the counselors' continuing education and training programs in China are confined to counselors' job responsibilities and basic working methods. These courses are of little value to the counselors and lack practical significance. However, there are few practical courses on how to make the work of counselors scientific, systematic and standardized. Finally, the serious shortage of counselors' continuing education and training is the direct cause of their quality problems. At present, the continuing education and training of college counselors are almost entirely dependent on colleges and universities, so training funds are basically all from the government and universities. There is no market mechanism shared by individuals, schools, governments and the society, as a result, there is not enough funds for the continuing education and training of counselors. Lack of funding support, even if the relevant personnel are concerned with the continuing education and training of the, it will also appears to be "Spirit is willing, but the flesh is weak".

\section{OPTIMIZED PATH OF COUNSELORS' CONTINUING EDUCATION}

\section{A. Strengthen the Awareness of Counselor's Continuing Education and Training}

Continuing education awareness of colleges and counselors is a prerequisite to carry out the work of counselors. In order to strengthen the importance of continuing education for counselors in colleges and universities, we should make great efforts in the following three aspects. At the national level, we should promote the formulation and implementation of continuing education policy for counselors, urge colleges and universities to enhance their awareness of continuing education and pay more attention to the continuing education of counselors.
Through the establishment of continuing education policy of counselors, the state can encourage colleges and universities in the process of implementing the continuing education of counselors to carry forward the spirit of innovation, innovate the mode and method of continuing education and training of counselors, and select the best and the most important ones to give priority support to them. To establish a group of guidance colleges and universities for continuing education, and to improve the enthusiasm of college counselors in continuing education by using the model law. At the university level, the school should actively implement the policy of continuous education of counselors issued by the state, formulate corresponding regulations and put the continuing education of counselors on the important agenda and timely obtain the results of continuing education training of counselors. The corresponding reward system and punishment system should be applied to the counselors who are outstanding in the process of continuing education, so as to realize the mechanism of direct link between the continuing education of counselors and their performance. In addition, we should also improve the treatment of counselors, eliminate the differences between counselors and teaching teachers, and give recognition and affirmation to the value of counselors. On the personal level, the counselors should be guided to form the consciousness of lifelong learning, to improve the counselors ' sense of identity and belonging to their own profession, and to induce the internal force of the counselors ' continuing education. Only in this case can counselors send their hearts to take continuing education and training as an important way to improve their professional quality, enhance their professional skills, and can have sufficient internal driving force for continuing education and learning, so that continuing education and training can play a practical role.

\section{B. Establish the Continuing Education System for Counselors}

First of all, we should perfect the system of counselors' continuing education. The state and universities should attach importance to the establishment of the system so as to make it practical and operable. By formulating the system of training, assessment, rewards and punishments for counselors, "The training and effect of full-time counselors should be regarded as the important basis for title evaluation, promotion, annual examination and salary improvement, and then promote the integration of counselor's continuing education system and other counselors' system"[4]. Secondly, it is necessary to open up and innovate the training mode of continuing education for counselors, change the current closed situation of relying on the colleges and universities, and lead the work of continuing education of counselors to the whole country and even to the world. On the one hand, it is necessary to build a network system of continuing education for counselors across the country and institutions at all levels, form a four-level institutional level of national, provincial, university and faculty and a three-level system of primary, intermediate and advanced cohesion, and create a large number of political instructors with professional knowledge and skills. On the other hand, we should be good at relying on network education, cooperative education, open 
schools and other forms to promote diversification and development of counselors' continuing education mode, and gradually form a group of counselors' training base and network system and set up an open and interactive counselor continuing education platform. Furthermore, establish the system of academic qualifications and degrees for counselors in continuing education. In college departments set up a specialized specialty about counselor's work. Like other majors and subjects, it will be a full-time program that takes merit from high school graduates and undergrads. After long running practice, we need to establish various levels of running schools, such as undergraduate students, second bachelor degree students, master degree students, doctorate students, and so on, then we can stand on our own by a complete discipline and specialty in our country's higher education, promote the regularization, institutionalization and scientification of the continuing education of political counselors and the political counselors can have the direction and the drive to learn. Finally, support for the establishment of a series of organizations related to the continuing education of counselors, such as the instructor's teaching and research department, the counselor's work research association, the counselor's work seminar and exchange center, etc. These organizations can provide communication sites and platforms for counselors to carry out theoretical research, exchange of experiences and declaration of scientific research subject, which is of great significance to strengthen communication between counselors. In addition, through the exchange of these platforms and the sharing of experiences, counselors can also enjoy the fun of career development and increase their professional identity and professionalism.

\section{Improve the Quality of Counselor's Continuing Education and Training}

To improve the quality of continuing education and training of counselors, measures should be taken mainly in three aspects: safeguard mechanism, curriculum and teaching, and training funds. On the safeguard mechanism of continuing education for counselors, on the one hand, strict training standards should be established in order to make the continuing education curriculum rule-based; on the other hand, it is also needed to improve the evaluation criteria of counselors ' continuing education to ensure the effectiveness of training. On this basis, according to training standards and evaluation criteria to strengthen the quality of continuing education of college counselors, "supervise the teaching content, teaching organization and teaching effect regularly to ensure the teaching quality of the training institutions[5]". In the course and teaching, the first is to update the content of the course so that it cannot only adapt to the needs of the new era students ' professional quality, but also be able to meet the needs of the development of higher education reform and the personality development of the counselors; the second is to broaden teaching forms, to change the present situation of relying solely on lectures and short-term training, and to make the counselors ' further education more convenient and flexible by using the way of network learning and amateur learning, and to rely on a variety of new platforms such as micro-course and curriculum learning network to make the counselor's continuing education and learning appear in the counselor's life in a new way, and then to realize the desire of counselors to learn everywhere and to learn from time to time. In the continuing education and training fund for counselors, on the one hand, try to increase the investment of the counselor's continuing education and training and allocate special funds to support it. These funds must be used exclusively for its intended purpose; On the other hand, we should introduce market mechanism into the funding mechanism of counselors ' continuing education, distribute the funds of all parties in the continuing education of counselors according to the principle of stakeholder, and promoting the healthy development of the investment mechanism of continuing education for counselors.

\section{CONCLUSION}

College counselors shoulder the important task of ideological and political education for college students. They not only want to teach students how to be a better person, but also they are the managers of college students' life and study, so the group of counselors is the most exposed group of college students. Their professional accomplishment may have a far greater impact on college students than teaching teachers and other school staff, they are the closest people to college students, and they are supposed to be the people most trusted by college students. With the serious decline of social morality, we should not only pay attention to the cultivation of college students' knowledge literacy and neglect the cultivation of their moral literacy again and again. The professional accomplishment of the counselor has a direct influence on the moral quality of the students, and the counselor should undoubtedly be the direct related person to improve the moral quality of the college students. The process of college counselors on the road of specialization will be full of twists and turns and difficulties. It needs the efforts of the country, colleges and universities, counselors themselves and even all walks of life.Only by formulating a complete system of continuous education for counselors, perfecting the teaching and curriculum system, and ensuring the learning effect, can the mission be better accomplished.

\section{REFERENCES}

[1] Feng Jianqiao, "Continuing education and comprehensive quality improvement of college counselors[J]" continuing education research, 2012(12): pp. 15-16.

[2] Wang Zhigang, Zhang Yinghuan and Jiang Hongmin, "Problems and countermeasures in continuing education of college counselors[J]" pharmaceutical research, 2013-29 (3): pp.44-46.

[3] Chu Jianjun, "Talking about constructing continuing education system for college counselors[J]" educational exploration, 2009(10): pp.173-175.

[4] Mao Ling, "Philosophical reflections on the continuing Education of college counselors[J]" 2010(10): pp. 57-58.

[5] Wang Zhigang, Zhang Yinghuan and Jiang Hongmin, "Problems and countermeasures in continuing education of college counselors[J]" pharmaceutical research, 2013-29 (3): pp.44-46. 